\title{
MEASUREMENT OF TOTAL BODY EXCHANGEABLE POTASSIUM AND ERYTHROCYTE POTASSIUM IN NEPHROTIC CHILDREN 1, 2
}

\author{
By DONALD GRIBETZ, LESLIE CORSA, JR., CHARLES D. COOK, HANS G. KEITEL, \\ AND NATHAN B. TALBOT
}

(From the Burnham Memorial Hospital for Children at the Massachusetts General Hospital and
the Department of Pediatrics, Harvard Medical School, Boston, Mass.)

(Submitted for publication June 12, 1953; accepted August 11, 1953)

Studies were undertaken to appraise the cellular potassium status of children with the nephrotic syndrome, utilizing two techniques: Measurement of total body exchangeable potassium $(\mathrm{Ke})$ by isotope dilution and determination of the potassium content of red blood cells by direct chemical analysis. The $\mathrm{Ke}$ values obtained on the nephrotic children are compared to similar data obtained on "hospital normal" children (1). The erythrocyte potassium values are compared to those obtained on normal adults (2).

\section{PATIENTS AND METHODS}

As shown in Table $I$, these studies were performed on nine nephrotic children, one to fourteen years of age. All but one of the patients (No. 8) were males. All had generalized pitting edema of insidious onset, hypoproteinemia, hypercholesterolemia, and albuminuria. None of the patients demonstrated a consistent elevation in blood pressure. Marked anemia, hematuria, acidosis, and sustained azotemia were absent. Urea clearance measurements were performed on five patients. In patients $5,7,8$, and 9 the values ranged between 57 and 94 per cent of normal; in patient number 6 it was 35 per cent. During the time when the above investigations were being carried out the patients were cared for on the Metabolic Unit of the Children's Medical Service and were taking diets which contained normal amounts of calories, protein, and potassium for age, and between 10 and $50 \mathrm{mEq}$. sodium per square meter of body surface per day.

Ten Ke determinations were performed on seven of the children according to the procedure described elsewhere (1). A dose of 1.5 to 3.0 microcuries of $\mathrm{K}^{42}$ per kilogram of body weight was used. ${ }^{3}$ The Ke values were cal-

1 This work was supported by grants from the Commonwealth Fund of New York, Mead Johnson and Company, and the Playtex Park Research Institute.

2 Read before the Society for Pediatric Research, May, 1952.

8 We are indebted to Dr. Arthur K. Solomon and to Miss Dorothy Driscoll of the Biophysical Laboratory of Harvard Medical School for processing the dry "target" material which was supplied by Brookhaven National Laboratory on allocation from U. S. Atomic Energy Commission. culated from the specific activity of urine collected between the twentieth and twenty-fourth hours after injection of the radioactive material. $\mathrm{Ke}$ at this time represents about 90 per cent of total body potassium (3). Reproducibility of this technique, expressed as the difference between duplicate determinations, is approximately five per cent of the mean ( 3 ).

Seventeen erythrocyte potassium determinations were performed on eight of the patients by methods described in detail in another communication (2). These data are reproducible within one per cent.

Urinary preformed creatinine was determined by a modification of the method of Bonsnes and Taussky (4).

\section{RESULTS}

The $\mathrm{Ke}$ values obtained on the present group of nephrotic patients are recorded in Column 7 of Table I.

Figures 1, 2, and 3 depict the relation of these $\mathrm{Ke}$ values to body weight, height, and 24-hour urinary creatinine output. For comparative purposes, these figures also indicate the respective relations between $\mathrm{Ke}$ and weight and height found in a group of thirteen "hospital normal" children " and between $\mathrm{Ke}$ and urinary creatinine output found in six of these "normal" children (1).

It may be seen in Figure 1 that the Ke values per kilogram edematous weight of these nephrotic children (mean 29; range 20 to $44 \mathrm{mEq}$. per $\mathrm{Kg}$.) are low relative to those obtained in the "hospital normal" children (mean 39; range 32 to $47 \mathrm{mEq}$. per $\mathrm{Kg}$.). When related to "non-edematous" weight (Column 5, Table I) a mean value of 36 $\mathrm{mEq}$. with a range of 27 to 47 per $\mathrm{Kg}$. is obtained.

Figure 2, in which the total $\mathrm{Ke}$ values are plotted against height, reveals that the nephrotic $\mathrm{Ke}$ val-

4 This "hospital normal" group was made up of children between one month and 14 years of age in good nutritional state who were hospitalized for diagnostic studies or were convalescing from acute infections. None had any condition known to be characterized by major alterations in bodily potassium content. 
TABLE I

Observations on nephrotic children

\begin{tabular}{|c|c|c|c|c|c|c|c|c|}
\hline $\begin{array}{l}\text { Case } \\
\text { no. }\end{array}$ & Age & $\begin{array}{c}2 \\
\begin{array}{c}\text { Duration } \\
\text { of } \\
\text { disease }\end{array} \\
\end{array}$ & $\begin{array}{c}3 \\
\text { Height }\end{array}$ & $\begin{array}{c}4 \\
\text { Weight } \\
\text { at time } \\
\text { of study }\end{array}$ & $\begin{array}{c}5 \\
\text { "Non- } \\
\text { edematous" } \\
\text { weight*" }\end{array}$ & $\begin{array}{c}6 \\
\text { Urinary } \\
\text { preformed } \\
\text { creatinine }\end{array}$ & $\begin{array}{c}7 \\
\quad 7 \\
\text { Exchange- } \\
\text { able } \\
\text { potassium }\end{array}$ & $\begin{array}{c}8 \\
\text { Erythro- } \\
\text { cyte } \\
\text { potassium }\end{array}$ \\
\hline & Yrs. & Mos. & $\mathrm{cm}$. & $K_{\mathbf{g}}$. & Kg. & mg. per $24 \mathrm{hr}$. & $m E q$. & $\begin{array}{l}m E q . \text { per } \\
K_{\boldsymbol{g}} \text {. solids }\end{array}$ \\
\hline 1 & $\begin{array}{ll}1 & 3 / 12 \\
1 & 6 / 12 \\
1 & 9 / 12 \\
1 & 10 / 12\end{array}$ & $\begin{array}{l}1 \\
4 \\
7 \\
8\end{array}$ & $\begin{array}{l}80 \\
81 \\
81 \\
82\end{array}$ & $\begin{array}{l}14.2 \\
14.4 \\
17.8 \\
13.5\end{array}$ & $\begin{array}{l}11.1 \\
10.8\end{array}$ & 155 & $\begin{array}{l}420 \\
375\end{array}$ & $\begin{array}{l}264 \\
260 \\
283 \\
267\end{array}$ \\
\hline 2 & $22 / 12$ & 2 & 93 & 18.4 & 14.9 & & 481 & 280 \\
\hline 3 & $28 / 12$ & 8 & 92 & 17.5 & 13.0 & & 350 & 247 \\
\hline 4 & $33 / 12$ & 9 & 103 & 25.6 & & & & 283 \\
\hline 5 & $43 / 12$ & 5 & 103 & 19.6 & & & & 295,285 \\
\hline 6 & $43 / 12$ & 24 & 103 & 20.9 & 15.5 & & 528 & \\
\hline 7 & $\begin{array}{l}44 / 12 \\
45 / 12\end{array}$ & $\begin{array}{l}37 \\
38\end{array}$ & $\begin{array}{l}106 \\
106\end{array}$ & $\begin{array}{l}21.0 \\
20.8\end{array}$ & $\begin{array}{l}17.4 \\
17.4\end{array}$ & $308,326,337$ & $\begin{array}{l}609 \\
565\end{array}$ & $\begin{array}{l}269,275 \\
262,275\end{array}$ \\
\hline 8 & $\begin{array}{ll}5 & 3 / 12 \\
5 & 11 / 12\end{array}$ & $\begin{array}{l}34 \\
42\end{array}$ & $\begin{array}{l}111 \\
115\end{array}$ & $\begin{array}{l}18.9 \\
28.4\end{array}$ & $\begin{array}{l}16.1 \\
20.1\end{array}$ & $\begin{array}{c}311,325,304 \\
226\end{array}$ & $\begin{array}{l}710 \\
759\end{array}$ & $\begin{array}{l}269 \\
275\end{array}$ \\
\hline 9 & $143 / 12$ & 11 & 144 & 34.0 & 31.5 & 714,900 & 1490 & 329 \\
\hline
\end{tabular}

* These values are approximate and probably are slightly in excess of the patient's true non-edematous weight.

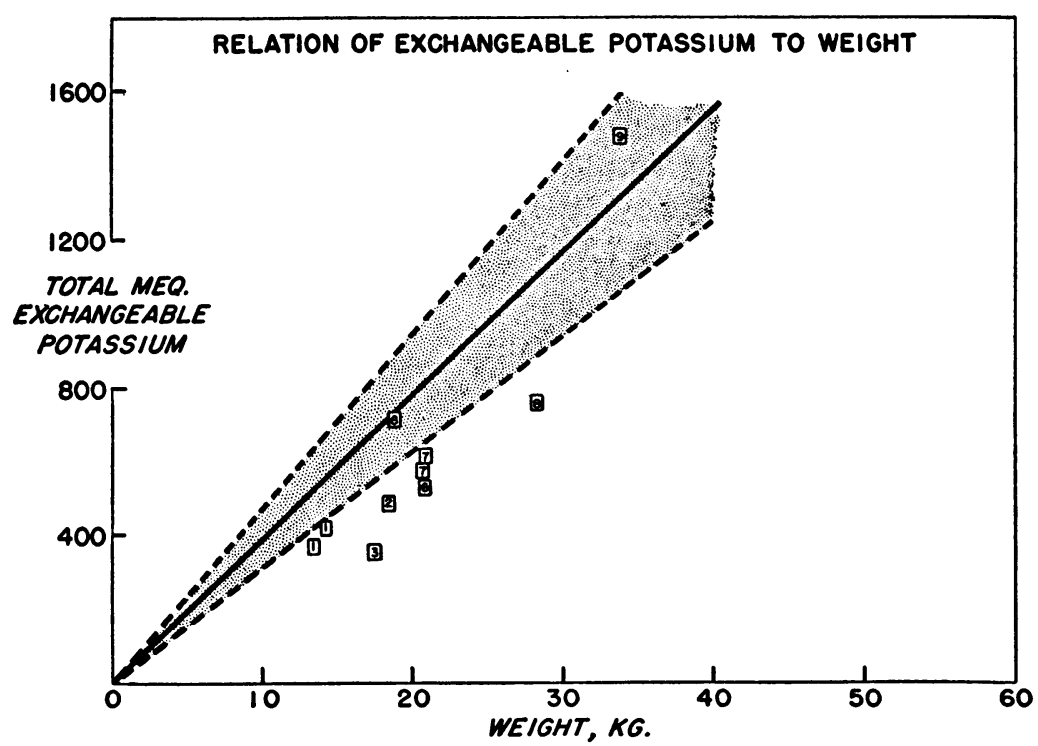

Fig. 1. Exchangeable Potassium Values of Nephrotic Patients (SQuares) Related to Body Weight

The numbers shown within the squares correspond to the patient case numbers of Table I. The interrupted diagonal lines outlining the shaded zone indicate the upper and lower limits of normal, respectively; the solid diagonal line indicates the normal mean. 


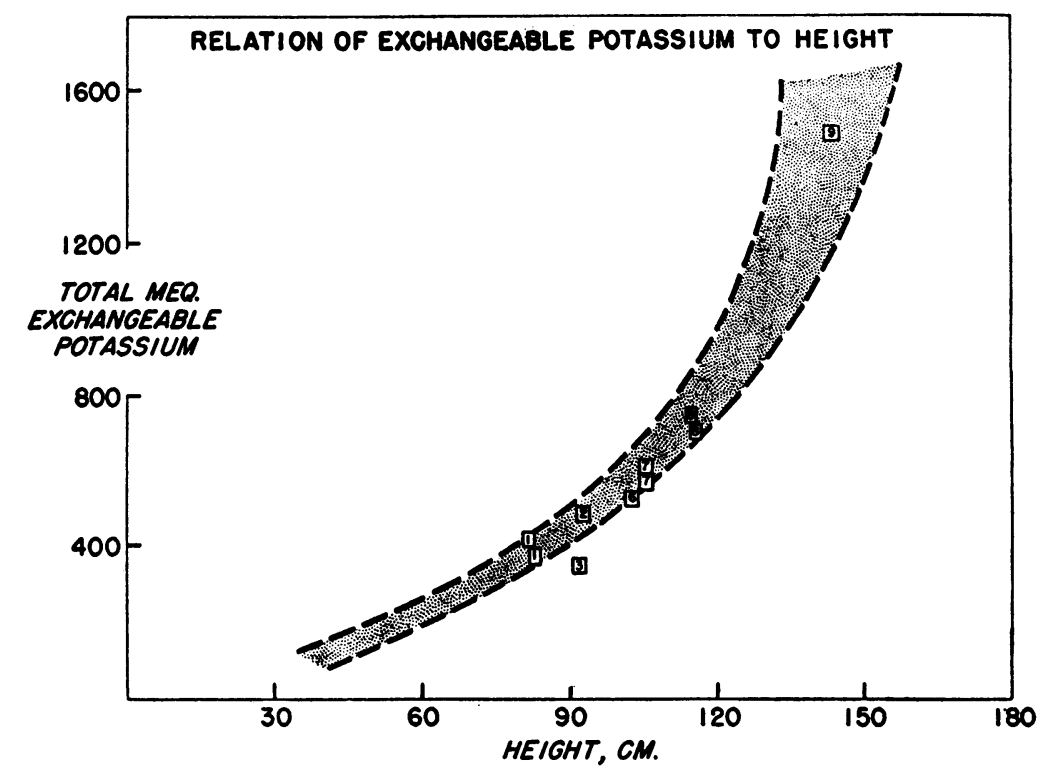

Fig. 2. Exchangeable Potassium Values of Nephrotic Patients ReLATED TO BODY Height

The design of this figure is similar to that of Figure 1 except that the normal mean is omitted.

ues conform well to the range found for the "hospital normal" children.

Figure 3 demonstrates that there is no obvious difference between nephrotic and "hospital normal" children when the $\mathrm{Ke}$ values are plotted against the 24-hour urinary output of preformed creatinine.

Column 8, Table I tabulates, and Figure 4 depicts the erythrocyte potassium contents of the nephrotic children related to the normal range of $254 \mathrm{mEq}$. to $290 \mathrm{mEq}$. per $\mathrm{Kg}$. of red blood cell solids found for adults in this laboratory (2). Values obtained from normal children approximate these normal adult data (5). It can be seen that in the majority of instances, regardless of the degree of edema, the values lie within the normal range.

\section{DISCUSSION}

These observations indicate that the $\mathrm{Ke}$ values of this group of nephrotic children, though low when viewed in relation to edematous weight, fall within normal limits in most instances when related to such indices of protoplasmic mass as height, "nonedematous" weight, and 24-hour preformed uri- nary creatinine. ${ }^{5}$ These are the relations which one would expect under circumstances where body weight is made up to an abnormal extent of potassium-poor edema fluid. The potassium content of isolated erythrocytes was also normal.

In these connections it is noteworthy that the present group did not appear to be severely wasted as sometimes is the case when children with nephrosis suffer intractable edema and anorexia over long periods of time. Moreover, gross reduction in renal function with tendency to acidosis and loss of fixed base were absent at the time of study.

Few other data are available for comparison with above. Fox and Slobody found low intracellular potassium concentration in muscle tissue obtained at autopsy (9). Comparison of these data with those presented here is difficult because of two factors. Four of the six patients studied by these authors were apparently in advanced stages of the nephrotic syndrome. Secondly, the patients studied by the above authors had all received heavy

5 Height and non-edematous weight ordinarily are roughly proportional to total bodily protoplasmic mass; urinary creatinine is considered an index of muscle mass. Available data indicate no effect of the nephrotic process per se on the metabolism of creatinine $(6-8)$. 


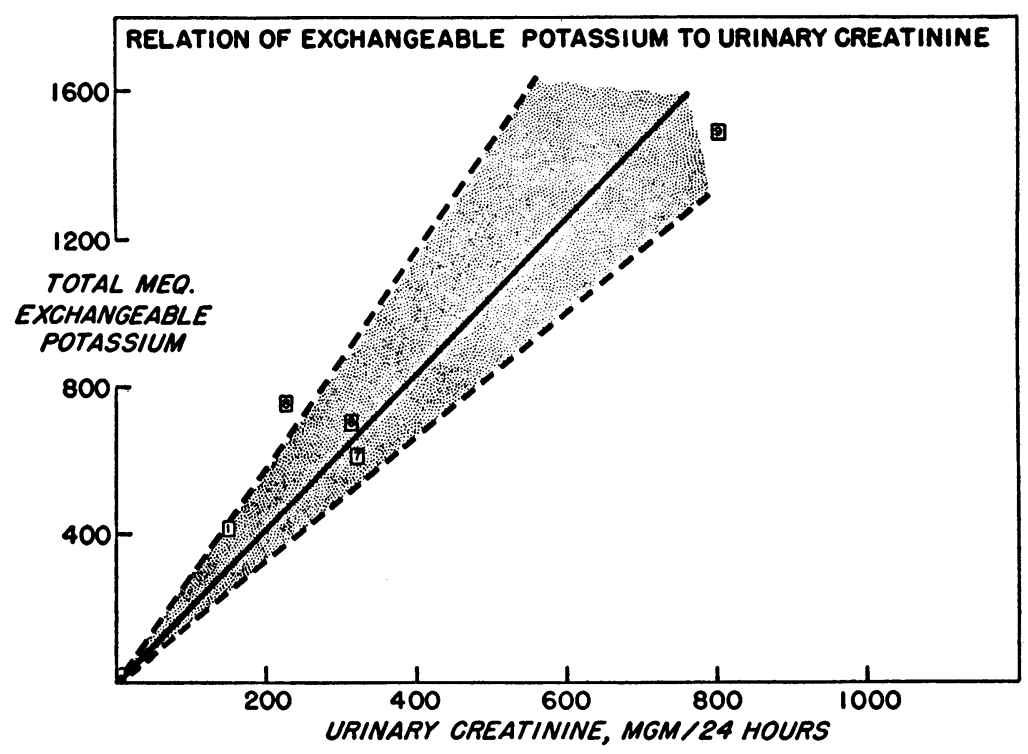

Fig. 3. Exchangeable Potassium Values of Nephrotic Patients Related to Urinary Preformed Creatinine Output

The design of this figure is similar to that of Figure 1.

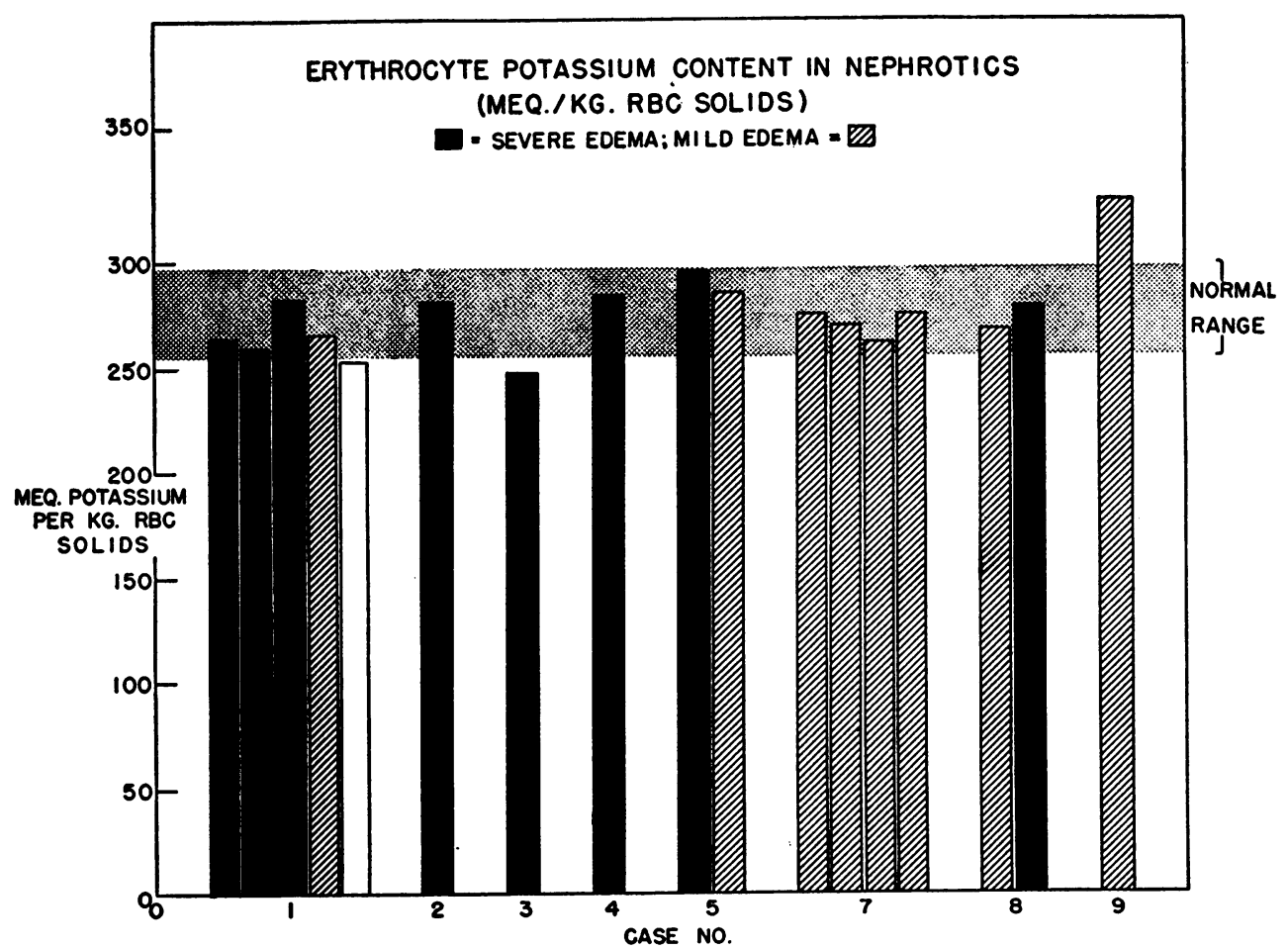

Fig. 4. Erythrocyte Potassium Values of Nephrotic Patients (Columns) Shown with Relation to Normal Range (Horizontal Shaded Area)

Values obtained at times when patients were very edematous are represented by solid black columns; those obtained at times when patients were relatively edema free are represented by the diagonally shaded columns. The clear, right hand column of Case No. 1 was obtained following ACTH therapy one day before death due to multiple causes. 
doses of sodium and potassium acetate. As shown by Darrow, such alkali therapy tends per se to cause cellular potassium deficiency $(10,11)$.

The studies reported, therefore, suggest that nephrotic patients may accumulate large amounts of edema without undergoing major change in cellular potassium status. This thesis is corroborated by balance data obtained on several of these patients which demonstrate little or no change in potassium balance despite large shifts in sodium balance (12).

\section{SUM MARY}

Cellular potassium status has been studied in nine nephrotic children using two techniques, $(a)$ the isotopic potassium-dilution method, and $(b)$ erythrocyte potassium determination. The total body exchangeable potassium values, though low with relation to total edematous body weight, were within normal limits when related to "nonedematous" weight, height, and urinary preformed creatinine output. The red blood cell potassium values also were well within normal limits.

\section{ACKNOWLEDGMENTS}

Credit is due Misses Ann M. Heeley, Lois Howell, Corinne Marr, Louise A. Miolene, and Florence Ridlon, nurses of the Metabolic Unit, for the accurate metabolic collections which made this investigation possible and to Miss Helen Berman and Mrs. Helen Jones for technical assistance.

\section{REFERENCES}

1. Corsa, L., Jr., Gribetz, D., Cook, C. D., and Talbot, N. B., In preparation.
2. Keitel, H. G., Berman, H., and MacLachlan, E. A., The chemical composition of normal human red blood cells, including variability among centrifuged cells. In press.

3. Corsa, L., Jr., Olney, J. M., Jr., Steenburg, R. W., Ball, M. R., and Moore, F. D., The measurement of exchangeable potassium in man by isotope dilution. J. Clin. Invest., 1950, 29, 1280.

4. Crawford, J. D., Osborne, M. M., Jr., Talbot, N. B., Terry, M. L., and Morrill, M. F., The parathyroid glands and phosphorus homeostasis. J. Clin. Invest., 1950, 29, 1448.

5. Overman, R. R., Etteldorf, J. N., Bass, A. C., and Horn, G. B., Plasma and erythrocyte chemistry of the normal infant from birth to two years of age. Pediatrics, 1951, 7, 565.

6. Flood, R. G., and Pinelli, R. W., Urinary glycocyamine, creatine and creatinine. II. Their excretion in children with the nephrotic syndrome. Am. J. Dis. Child., 1949, 78, 67.

7. Portier, A., Sabon, F., Mahon, C., et Massonnat, J., L'élimination urinaire de l'acide Quanidyl-acétique (glycocyamine) et des syndromes néphrotiques au cours de la néphrose lipoidique. Ann. méd., 1951, $52,734$.

8. Barnett, H., Personal communication to the authors.

9. Fox, C. L., Jr., and Slobody, L. B., Tissue changes in the nephrotic syndrome: Demonstration of potassium depletion. Pediatrics, 1951, 7, 186.

10. Darrow, D. C., Changes in muscle composition in alkalosis. J. Clin. Invest., 1946, 25, 324.

11. Darrow, D. C., Schwartz, R., Iannucci, J. F., and Coville, $F$., The relation of serum bicarbonate concentration to muscle composition. J. Clin. Invest., 1948, 27, 198.

12. Cook, C. D., Corsa, L., Jr., and Talbot, N. B., In preparation. 